\title{
Nutritional and therapeutic benefits of medicinal plant Pithecellobium dulce (Fabaceae): A review
}

\author{
Selvakumar Murugesan ${ }^{1}$, Dinesh Kumar Lakshmanan ${ }^{2}$, Velusamy Arumugam³ ${ }^{3}$ Ronaldo Anuf Alexander ${ }^{*}$ \\ ${ }^{1}$ Department of Biotechnology, Anna University, BIT Campus, Tiruchirappalli, India. \\ ${ }^{2}$ Department Environmental Biotechnology, Bharathidasan University, Tiruchirappalli, India. \\ ${ }^{3}$ Department Environmental Biotechnology, Bharathidasan University, Tiruchirappalli, India. \\ ${ }^{4}$ Centre for Research, Department of Biotechnology, Kamaraj College of Engineering and Technology, Virudhunagar, India.
}

\section{ARTICLE INFO \\ Received on: 07/12/2018 \\ Accepted on: 25/02/2019 \\ Available online: 01/07/2019}

Key words:

Pithecellobium dulce, legume, nutrients, phytochemicals,

therapeutic value.

\begin{abstract}
Pithecellobium dulce, an evergreen medium-sized, spiny tree, each part of the plant has vast nutritional values; stuffed with essential vitamins, amino acids, and minerals. The fruits of $P$. dulce were widely used in Ayurvedic medicines and home remedies. The plant has also been a rich source of biologically active compounds such as tannin, olein, and glycosides. Totally 38 active phytocompounds like quercetin, kaempferol, and dulcitol were identified from the various parts of the plant. Notably, this plant has catechol type of tannins in the bark. There are polyphenol classes of phytocompounds which have found to hold potent antivenom activity. Their fruits are a rich source of phenols, flavonoids, and saponins reported for their efficacy to treat diabetes, oxidative stress, and gastrointestinal disorders. The plant leaf and seed have an antibacterial, antifungal, and adulticidal activities. Thus, the present review describes on exploiting the medicinal properties of $P$. dulce and its biomedicinal applications in therapeutic development.
\end{abstract}

\section{INTRODUCTION}

Medicinal plants are the rich source of various natural constituents with extensive pharmacological activities. In recent days, nutraceuticals have gained huge attention as nutritional supplements for their positive physiological effects in the human body (Bagchi and Kumar, 2016). From villages to developed cities, traditional ways of natural medication consecutively becoming popular. Notably, the plant-derived compounds hold huge precious values for healthy living, and the tribal and elders have well known about the plants decades ago (Shyur and Yang, 2008). Lot of bioactive phytochemicals with medicinal properties to cure various health illnesses has been revealed every day by researchers (Satheesh Kumar and Nisha, 2014). These plantderived bioactive compounds have the enormous potentiality to

\section{"Corresponding Author}

Ronaldo Anuf Alexander., Department of Biotechnology, Kamaraj College of Engineering and Technology, Virudhunagar, Tamil Nadu, India.

E-mail: ronaldoanufbt@yahoo.com treat diseases like diabetes, cancer, inflammation, etc. (Saklani and Samuel, 2008). Although, there are numbers of allopathic drugs which have been developed every day since, the permanent recovery from the diseases and the secondary complications aroused during the medication remains a matter of debate (Edzard Ernst, 1998). Sometimes it would cause drastic effects like liver failure, kidney failure, raised blood pressure, and several other complications (Pirkle and Freedman, 2013). We have vast diverse flora with unexplored medicinal values (Hooper and Aedin, 2006). Pithecellobium dulce ( $P$. dulce) is an important fruit of American origin and it belongs to the family of Fabaceae, a native of tropical America, and is cultivated throughout India and Andaman (Rao et al., 2011). P. dulce is one among the category, which is an evergreen medium-sized, spiny tree. It is locally called "Jungal jalebi," "black bead tree" in English, "Vilayati Babul" in Hindi, and "Kodukkapuli" in Tamil (Orwa et al., 2009). This review discusses the overall bioactive constituents and their pharmaceutical properties of the $P$. dulce. 


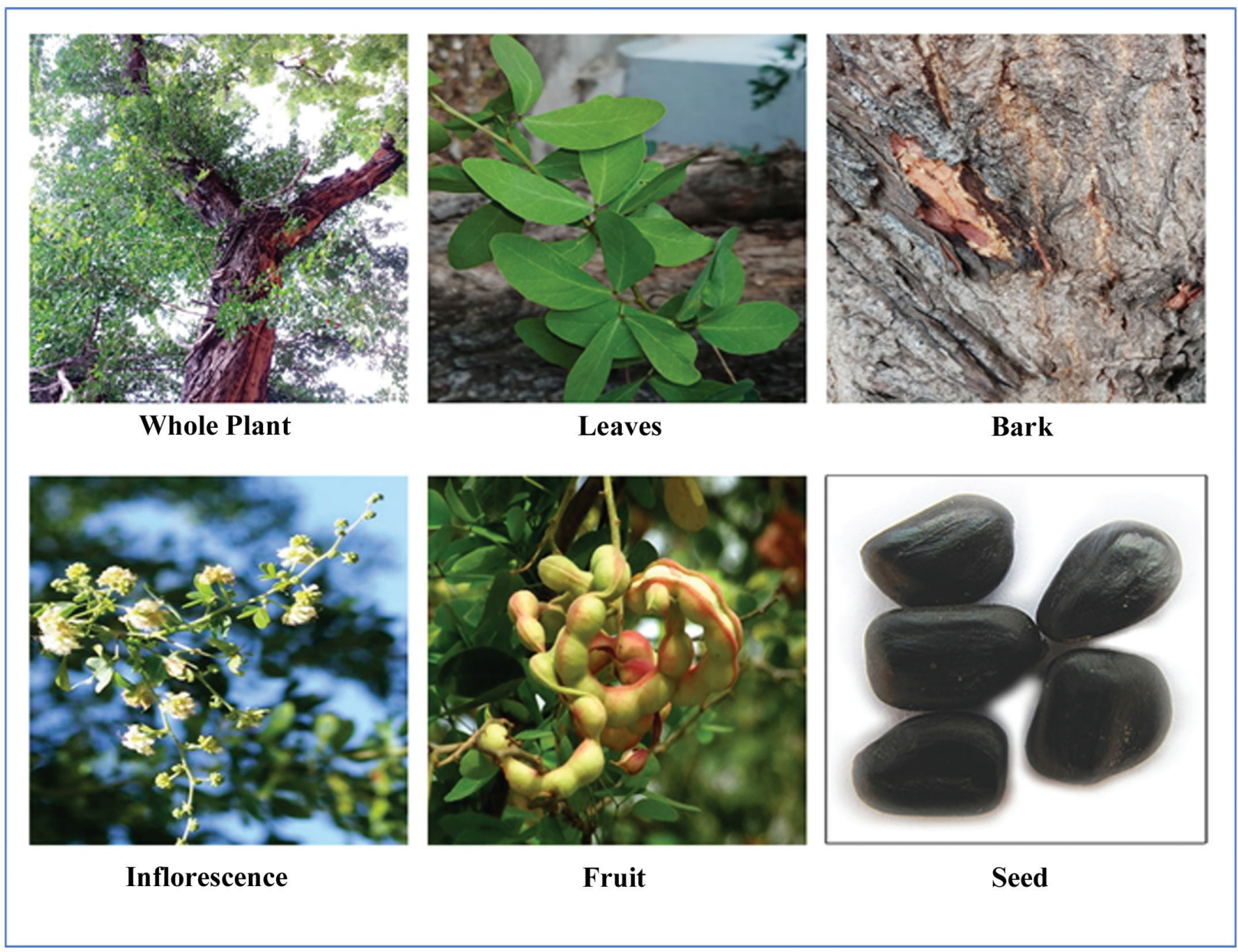

Figure 1. Pithecellobium dulce plant.

\section{Botanical description}

Domain: Eukaryota

Kingdom: Plantae

Phylum: Spermatophyta

Subphylum: Angiospermae

Class: Dicotyledonae

Order: Fabales

Family: Fabaceae

Genus: Pithecellobium

Species: Pithecellobium dulce

\section{Plant morphology}

The barks of $P$. dulce are gray in color, they become rougher and eventually start peeling when gets matured. The leaves are 2-2.5 $\times 1-2 \mathrm{~cm}$ in size and have kidney-shaped leaflets with a pair of two leaves. Each leaf has a thin spine of $2-15 \mathrm{~mm}$ at the leaf base. Hairy corolla shaped flowers of $1 \mathrm{~cm}$ diameter are present with small whiteheads in the $P$. dulce. In the flowers, 50 thin stamens are surrounded in the calyx in a united tube. Each pod size is $10-15 \times 1.5 \mathrm{~cm}$ and spiral and reddishbrown as they ripen (Orwa et al., 2009). The parts of the plant were shown in Figure 1.

\section{Plant distribution}

The plant originated from Brazil, Argentina, Bolivia, Colombia, etc., $P$. dulce is one of the species that has become widespread outside from its origin. It is one of 18 species in this genus. It has been distributed naturally in many countries like India, Huawei, tropical Africa, and especially along the coast (Orwa et al., 2009). The species distribution map for $P$. dulce is shown in Figure 2.

\section{NUTRITIONAL VALUES}

The fruits and seeds of $P$. dulce contain vital vitamins like ascorbic acid, thiamine, riboflavin, and some essential amino acids like lysine, phenylalanine, tryptophan, and valine, as shown in Figure 3 and few essential minerals such as $\mathrm{Na}, \mathrm{K}, \mathrm{P}, \mathrm{Fe}$, and $\mathrm{Ca}$, as shown in Figure 4 and secondary metabolite classes like tannins, $25.36 \%$ fixed oil, and $18.2 \%$ olein are found in the $P$. dulce (CSIR, 1988). Catechol, a notable type of tannin compound which is present in the bark (37\%). Quercetin, afezilin, kaempferol, and dulcitol were identified from the leaf extract of $P$. dulce. Its fruit contains phenols, flavonoids, and saponins. The phenolic and flavonoids have a hydroxyl functional group that possesses radical scavenging ability to prevent oxidative damage (Katekhaye and Kale, 2012). Proteins and peptides with the potential to combat 


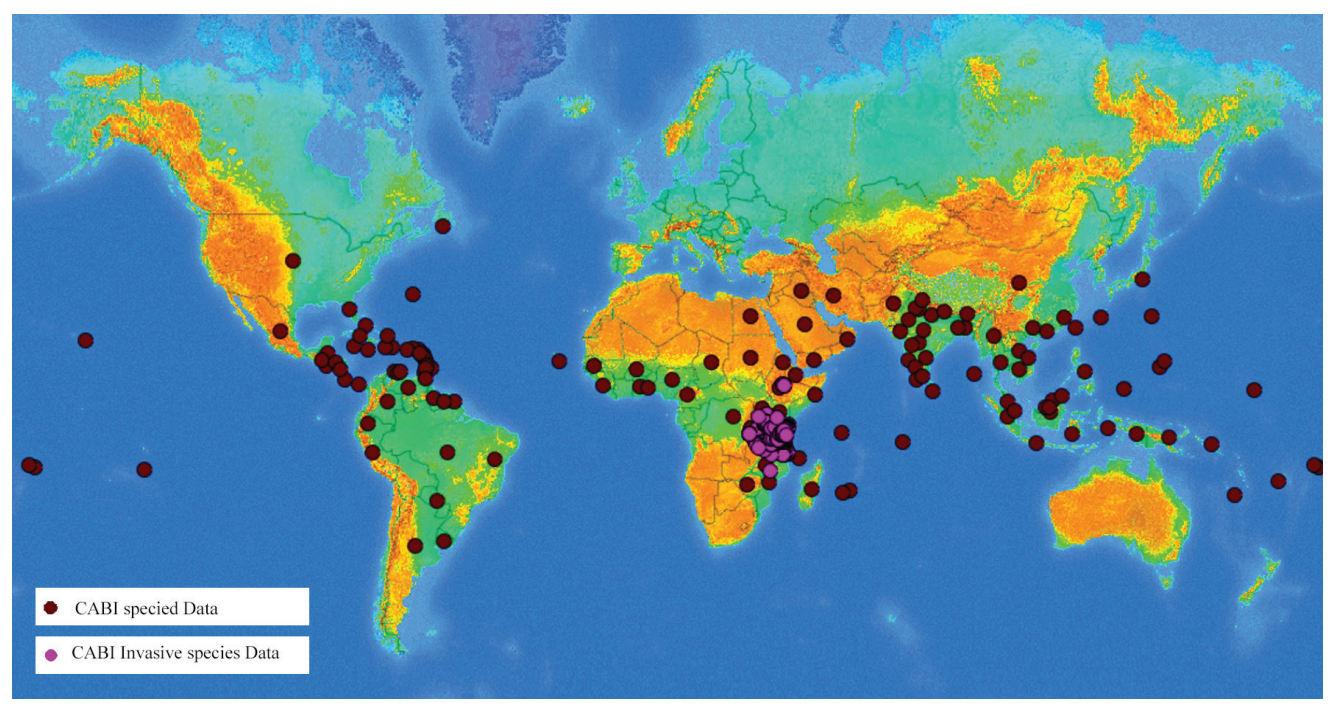

Figure 2. World Distribution of Pithecellobium dulce.

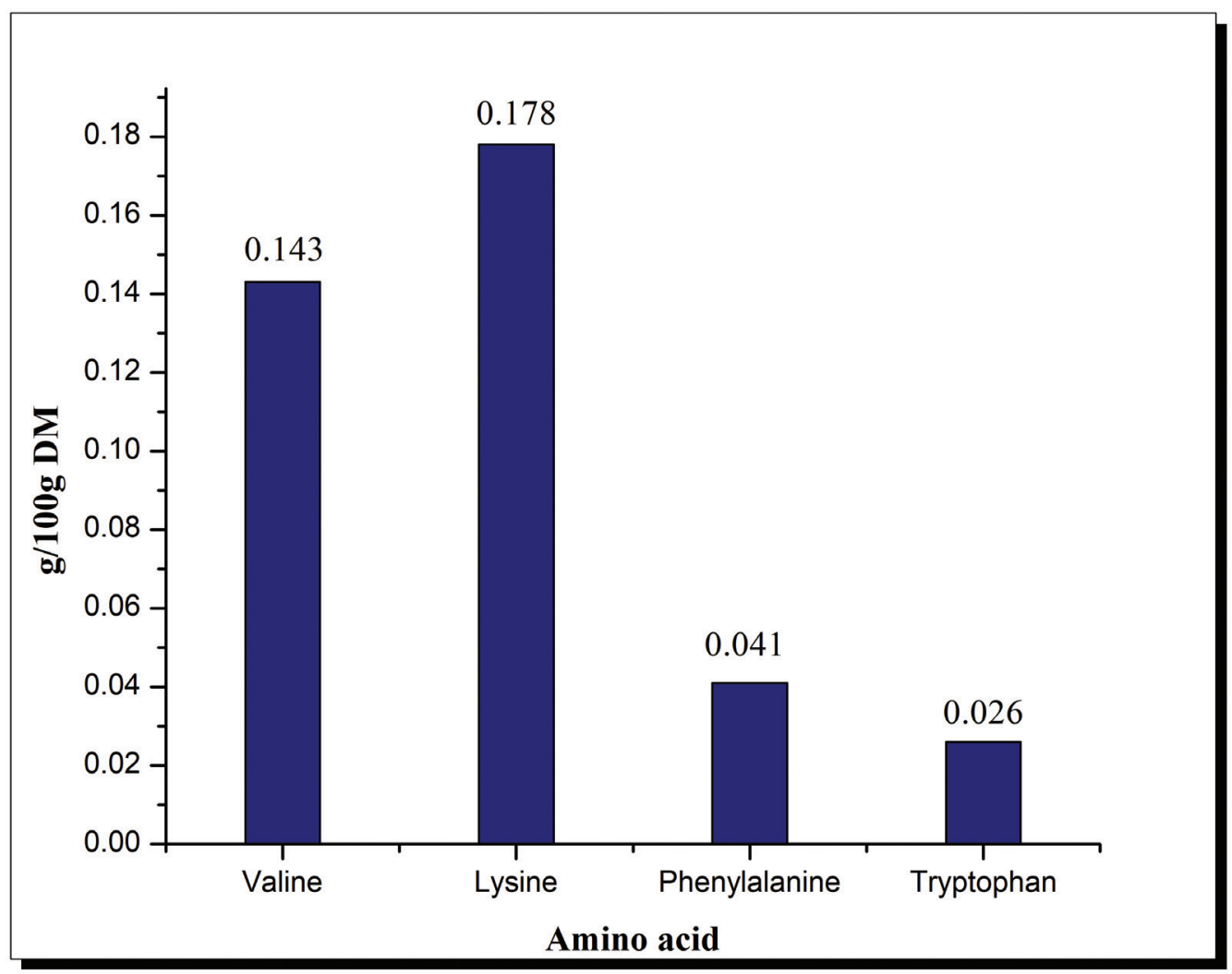

Figure 3. Essential amino acids in Pithecellobium dulce fruits.

protein malnutrition are richly present in $P$. dulce seeds. The steroid, saponin, lipids, phospholipids, glycosides, glycolipids, and polysaccharides are present in $P$. dulce seeds. The lists of phytochemical constitutions and their structures were shown in Table 1 and Figure 5. Recently, the alkylated resins were identified from the seed oil. The water-soluble polysaccharides were isolated from the seeds and are used as humanoid ailments; it also has an anti-oxidant activity that prevents the oxidative stress (Bagchi and
Kumar, 2016). Three different hetero-polysaccharides are isolated from $P$. dulce fruits; those were used as pharmaceutical adjuvants (Preethi and Mary Saral, 2016). The protein and fiber contents of $P$. dulce are shown in graph Figure 5. The entire plant of $P$. dulce has medicinal values and its leaves are also used as a feed for goat (Kahindi et al., 2007) because of its good nutritional content (Olivares et al., 2013). 


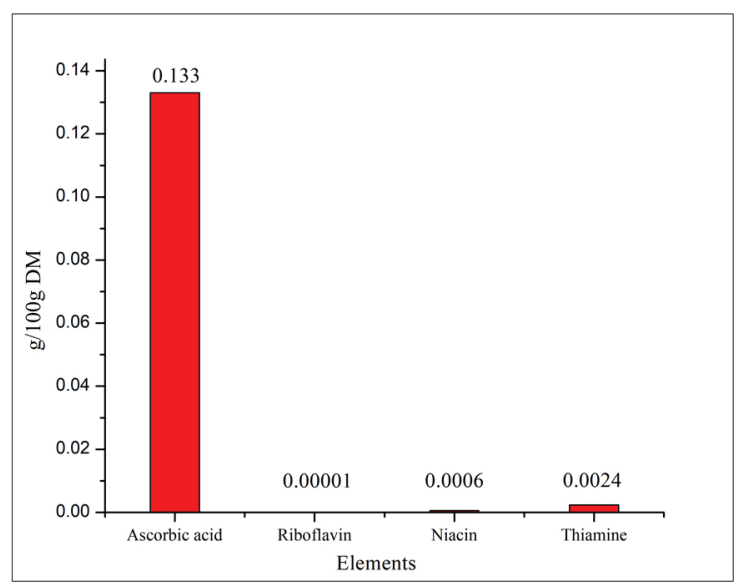

Figure 4. Nutritional composition of Pithecellobium dulce fruits.

\section{THERAPEUTIC AND BIOLOGICAL VALUES OF P. DULCE}

Each part of the plant $P$. dulce contains notable medicinal values, like the estrogenic activity was proposed in the root extracts (Saxena et al., 1998), the anti-inflammatory activity of the saponin fraction of $P$. dulce fruits (Bhargvakrishna et al., 1970; Sahu and Mahato, 1994), and their various parts have been reported to be as a remedy for earache, leprosy, peptic ulcer, toothache, venereal disease, and it also acts as emollient, abortifacient, anodyne, and larvicides (Govindarajan et al., 2012). The bark of $P$. dulce also acts as an astringent for dysentery, febrifuge. In addition, this plant also has a useful remedy for dermatitis eye inflammation. The polyphenols content of the bark extract has reported for their anti-venomous activity by Pithayanukul et al. (2005). In seeds, active classes of phytoconstituents like steroids, saponins, lipids, phospholipids, glycosides, glycolipids, and polysaccharides were identified (Nigam and Mitra, 1968; 1970). This plant is a potential source of antioxidant and effective medicine for adulticide problem (Rajeswary and Govindarajan, 2014). The lists of biological therapeutic values were shown in Table 2. Beside of all the above properties, it is a nutritional feed for goats and other livestock (Olivares et al., 2013).

\section{Adulticidal activity}

The Phytochemicals of $P$. dulce are also used as an insecticide as they have an adulticidal activity against mosquitoes like Aedes aegypti ( $A$. aegypti), Culex quinquefasciatus $(C$. quinquefasciatus), etc. Dengue, filariasis, malaria, and viral encephalitis are major Mosquito-borne diseases in developing countries. Aedes aegypti mosquitoes are responsible for dengue fever. Chemical based mosquito repellent spray is usually toxic to other beneficiary life forms, may cause severe breathing problems in human too. To avoid such circumstances, naturally derived repellents can be used (Govindarajan and Rajeswary, 2015). The leaves and seed extracts of $P$. dulce have the tendency to control mosquitoes and are very safe. The larvicidal and ovicidal effects are moderate in the leaf and seeds of this plant. The comparison studies were undertaken and is reported that the leaf extract using methanol has the highest larval mortality and the seed extract using hexane have lower potency towards mosquitoes.

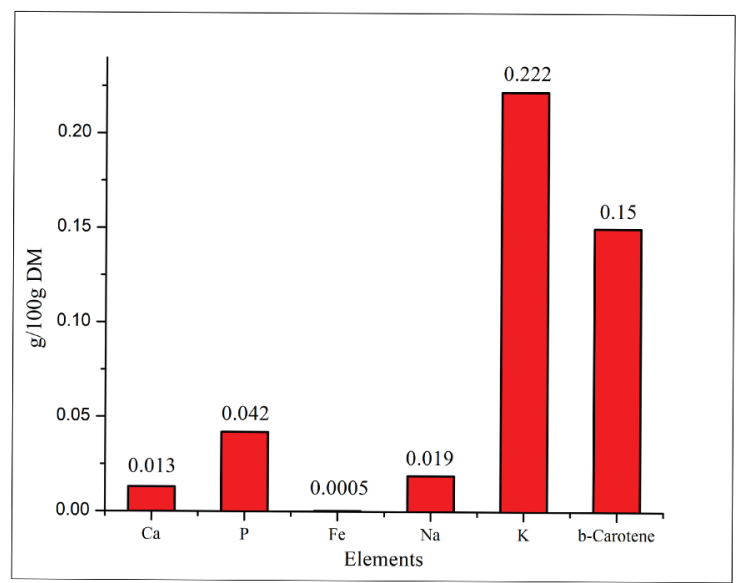

The larvicidal and ovicidal activities were proved in $A$. aegypti (Rajeswary and Govindarajan, 2014) and C. quinquefasciatus (Govindarajan et al., 2012) mosquitoes. Pithecellobium dulce derived bioactive compounds are also used as a natural synthetic insecticide. The silver nanoparticles synthesized from an aqueous extract of $P$. dulce's leaf exhibited larvicidal activity against $C$. quinquefasciatus. Further, the FT-IR report identifies the saponin; a class of phytocompounds in the plant is responsible for the synthesis of the silver nanoparticle (Raman et al., 2012).

\section{Anti-diabetic activity}

Diabetes mellitus is a very complex and uncontrollable metabolic disorder. There are numbers of the chemical agents that control the insulin and glucose level in the blood. It happens either due to improper secretion or action of insulin in the body during diabetes mellitus (Chaudhury et al., 2017). The synthetic pharmaceutical drugs prescribed for these conditions are having more harmful side effects like causing secondary organ damage (kidney failure, liver failure, etc.) on the human body. The plant bioactive chemicals are alternate medicines for diabetes allopathic medication. The methanolic crude extract of $P$. dulce seed was tested in Streptozotocin (STZ)-induced diabetic rat (albino Wistar male model) and the extract has the ability to protect the functional $\beta$-cells that produce and maintain the insulin level in the blood (Fu et al., 2013). This insulin treatment improves the glycogen content. In the methanolic extract treated STZ induced rats, the liver glycogen level was higher compared with the control group of Wistar rat and the functional glucose metabolism could be due to better insulin secretion from $\beta$-cells and the glucose was utilized in the oral glucose tolerance test. Thus, it could be a potential therapeutic for diabetic patients (Nagmoti et al., 2015). The $P$. dulce fruit containing a cyclic polyol pinitol and it has reported for having anti-diabetic activity (Gao et al., 2015; Kim et al., 2007).

\section{Anti-hyperlipidemic}

The excess glucose is usually preserved as glycogen and then fat in our body tissues as storage fuel for future. But the continuous accumulation for a longer period may lead to hyperlipidemia. It is one of the major risk factors involved in the development of Type II diabetes, heart disease, etc. 
Table 1. List of bioactive compounds reported in Pithecellobium dulce.

\begin{tabular}{|c|c|c|c|c|c|}
\hline S. No & Phytochemical name & Molecular formula & Molecular weight (g/mol) & Part of the plant & Reference \\
\hline 1 & Catechol & $\mathrm{C}_{6} \mathrm{H}_{6} \mathrm{O}_{2}$ & 110.10 & Bark & CSIR, 1980 \\
\hline 2 & Campesterol & $\mathrm{C}_{28} \mathrm{H}_{48} \mathrm{O}$ & 400.68 & Wood & \\
\hline 3 & Leucofisetinidin & $\mathrm{C}_{15} \mathrm{H}_{14} \mathrm{O}_{6}$ & 290.27 & Wood & \\
\hline 4 & Melacacidin & $\mathrm{C}_{15} \mathrm{H}_{4} \mathrm{O}_{7}$ & 306.26 & Wood & \\
\hline 5 & Hederagenin & $\mathrm{C}_{30} \mathrm{H}_{48} \mathrm{O}_{4}$ & 472.70 & Seeds & \\
\hline 6 & Pitheduloside A & $\mathrm{C}_{41} \mathrm{H}_{66} \mathrm{O}_{13}$ & 766.96 & Seeds & Nigam et al., 1996 \\
\hline 7 & Pitheduloside B & $\mathrm{C}_{46} \mathrm{H}_{74} \mathrm{O}_{16}$ & 883.08 & Seeds & \\
\hline 8 & Pitheduloside C & $\mathrm{C}_{46} \mathrm{H}_{74} \mathrm{O}_{16}$ & 883.08 & Seeds & \\
\hline 9 & Pitheduloside D & $\mathrm{C}_{46} \mathrm{H}_{74} \mathrm{O}_{17}$ & 899.08 & Seeds & \\
\hline 10 & Pitheduloside E & $\mathrm{C}_{46} \mathrm{H}_{74} \mathrm{O}_{17}$ & 899.08 & Seeds & \\
\hline 11 & Pitheduloside F & $\mathrm{C}_{52} \mathrm{H}_{84} \mathrm{O}_{21}$ & 1045.22 & Seeds & \\
\hline 12 & Pitheduloside G & $\mathrm{C}_{52} \mathrm{H}_{84} \mathrm{O}_{21}$ & 1045.22 & Seeds & \\
\hline 13 & Pitheduloside $\mathrm{H}$ & $\mathrm{C}_{100} \mathrm{H}_{158} \mathrm{O}_{49}$ & 2144.31 & Seeds & Yoshikawa et al., 1997 \\
\hline 14 & Pitheduloside I & $\mathrm{C}_{30} \mathrm{H}_{48} \mathrm{O}_{5}$ & 488.69 & Seeds & \\
\hline 15 & Pitheduloside J & $\mathrm{C}_{30} \mathrm{H}_{48} \mathrm{O}_{5}$ & 488.69 & Seeds & \\
\hline 16 & Pitheduloside K & $\mathrm{C}_{52} \mathrm{H}_{84} \mathrm{O}_{22}$ & 1061.21 & Seeds & \\
\hline 17 & Octacosanol & $\mathrm{C}_{28} \mathrm{H}_{58} \mathrm{O}$ & 410.76 & Leaves & Nigam et al., 1970 \\
\hline 18 & $\alpha$-spinasterol & $\mathrm{C}_{29} \mathrm{H}_{48} \mathrm{O}$ & 412.70 & Leaves & \\
\hline 19 & Kaempferol & $\mathrm{C}_{15} \mathrm{H}_{10} \mathrm{O}_{6}$ & 286.83 & Leaves & \\
\hline 20 & kaempferol-3-rhamnoside & $\mathrm{C}_{21} \mathrm{H}_{19} \mathrm{O}_{10}$ & 431.73 & Leaves & \\
\hline 21 & $\beta$ Glucoside $-\alpha$ spinasterol & $\mathrm{C}_{35} \mathrm{H}_{58} \mathrm{O}_{6}$ & 574.85 & Leaves & \\
\hline 22 & Pithogenin & $\mathrm{C}_{28} \mathrm{H}_{44} \mathrm{O}_{4}$ & 444.62 & Seeds & Nigam et al., 1962 \\
\hline 23 & Ellagic acid & $\mathrm{C}_{14} \mathrm{H}_{6} \mathrm{O}_{8}$ & 302.19 & Fruits & Megala and Geetha, 2009 \\
\hline 24 & Gallic acid & $\mathrm{C}_{7} \mathrm{H}_{6} \mathrm{O}_{5}$ & 170.12 & Fruits & \\
\hline 25 & Mandelic acid & $\mathrm{C}_{8} \mathrm{H}_{8} \mathrm{O}_{3}$ & 152.14 & Fruits & \\
\hline 26 & Ferulic acid & $\mathrm{C}_{10} \mathrm{H}_{10} \mathrm{O}_{4}$ & 194.18 & Fruits & \\
\hline 27 & Vanillic acid & $\mathrm{C}_{8} \mathrm{H}_{8} \mathrm{O}_{4}$ & 168.14 & Fruits & \\
\hline 28 & Coumaric acid & $\mathrm{C}_{9} \mathrm{H}_{8} \mathrm{O}_{3}$ & 164.16 & Fruits & \\
\hline 29 & Rutin & $\mathrm{C}_{27} \mathrm{H}_{30} \mathrm{O}_{16}$ & 610.52 & Fruits & \\
\hline 30 & Naringin & $\mathrm{C}_{27} \mathrm{H}_{32} \mathrm{O}_{14}$ & 580.54 & Fruits & \\
\hline 31 & Daidzein & $\mathrm{C}_{15} \mathrm{H}_{10} \mathrm{O}_{4}$ & 254.23 & Fruits & \\
\hline 32 & Dulcitol & $\mathrm{C}_{6} \mathrm{H}_{14} \mathrm{O}_{6}$ & 182.17 & Leaves & \\
\hline 33 & Quercetin & $\mathrm{C}_{15} \mathrm{H}_{10} \mathrm{O}_{7}$ & 302.23 & Leaves, fruits, fruit peel & \\
\hline 34 & Stigmasterol & $\mathrm{C}_{29} \mathrm{H}_{48} \mathrm{O}$ & 412.69 & Seeds, fruit peel & Sukantha and Subashini, 2015 \\
\hline 35 & Pinitol & $\mathrm{C}_{15} \mathrm{H}_{14} \mathrm{O}_{6}$ & 290.26 & Fruit peel & \\
\hline 36 & Prenylapigenine & $\mathrm{C}_{32} \mathrm{H}_{38} \mathrm{O}_{14}$ & 646.63 & Stem & \\
\hline 37 & Oleanolic acid & $\mathrm{C}_{30} \mathrm{H}_{48} \mathrm{O}_{3}$ & 456.70 & Seeds & \\
\hline 38 & Echinocystic acid & $\mathrm{C}_{30} \mathrm{H}_{48} \mathrm{O}_{4}$ & 472.70 & Seeds & \\
\hline
\end{tabular}

(Nelson, 2013; Zhou et al., 2015). High-density lipoprotein cholesterol (HDLC) is mainly involved in protecting us from heart diseases, especially atherosclerosis (Vergeer et al., 2010) and it transports excess cholesterol out of the body. Nagmoti et al. (2015) checked the methanolic crude extract of $P$. dulce seed on STZ-induced diabetic rat model. The histopathological analysis showed the increased levels of HDLC and the very low-density lipoproteins cholesterol (VLDLC), low-density lipoproteins cholesterol (LDLC), serum cholesterol, and triglycerides level were significantly decreased in the $P$. dulce treated rats. From the results, the bioactive compounds of $P$. dulce seeds have active potentiality against the hyperlipidemic condition. Hence, $P$. dulce could also holding hyperlipidemic activity against STZ induced animal model has been proved (Nagmoti et al., 2015).

\section{Anti-oxidant activity}

Imbalance of electron on any atom or oxidative stress is one of the key important factors which triggers majority of diseases like cancer, arthritis, diabetes, renal damage, etc. (Ung et al., 2017). The unstable radicals cause severe damage to the inner organs, tissues, and cause various health problems. Nitric oxide, hydroxyl, and superoxide radicals are few common free radicals responsible for some autoimmune diseases like rheumatoid arthritis 


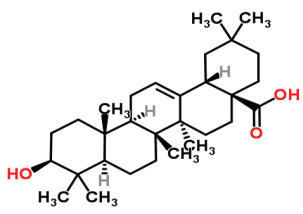

Oleanolic acid<smiles>O=c1c(O)c(-c2ccc(Cl)cc2)oc2cc(O)cc(O)c12</smiles>

Kaempferol<smiles>O=C(O)c1cc(O)c(O)c(O)c1</smiles>

Gallic acid

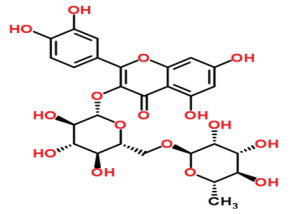

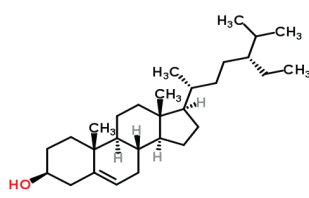

Echinocystic acid Glucoside of $-b$ sitosterol

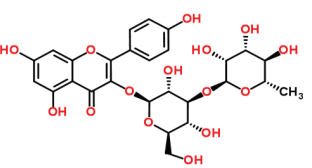

Kaempferol 3-rhamnoside
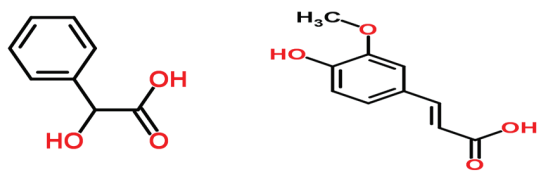

Ferulic acid

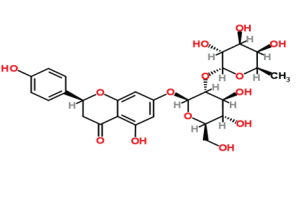

Naringin

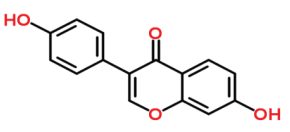

Daidzein<smiles>Oc1ccc([C@@H]2Oc3c(ccc(O)c3O)C(O)[C@H]2O)cc1O</smiles>

Melacacidin

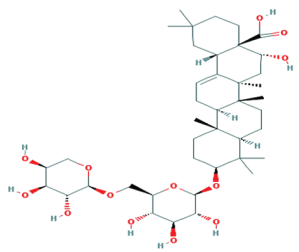

Pitheduloside A

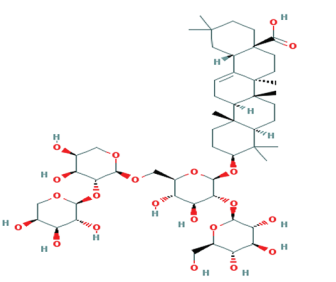

Pitheduloside F

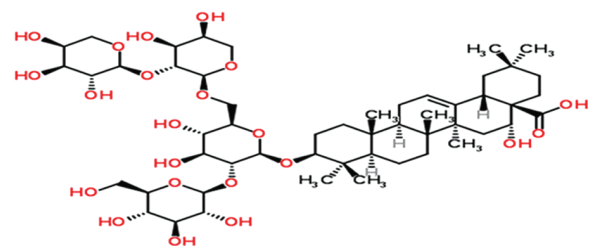

Pitheduloside K

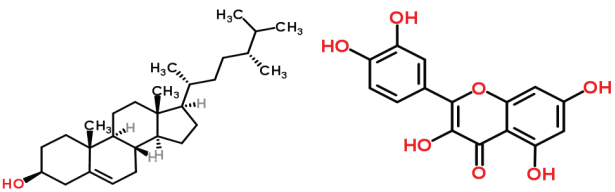

Campesterol

Quercetin

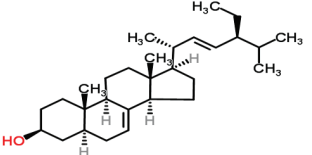<smiles>O=C(O)c1cc(O)c(O)c(O)c1</smiles>

Ellagic acid

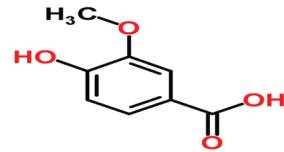

(2)

Vanillic acid 


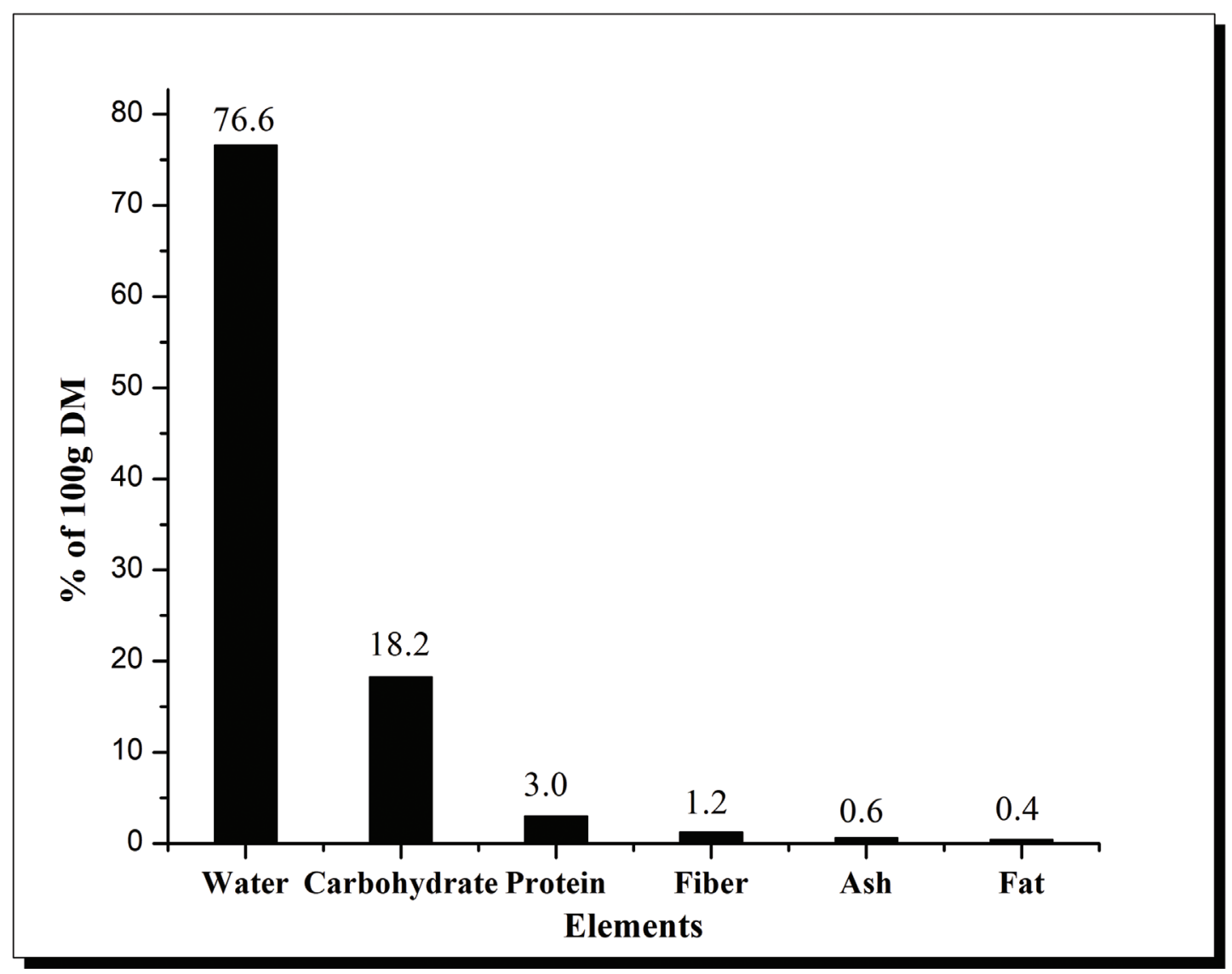

Figure 6. Composition of desiccated Pithecellobium dulce fruits.

Table 2. Pharmaceutical and biological effects of Pithecellobium dulce.

\begin{tabular}{|c|c|c|c|c|}
\hline S. no & Biological activity & Part of the plant & Extraction & Reference \\
\hline 1. & Adultical & Leaf and seed & $\begin{array}{l}\text { Hexane, Benzene, Chloroform, Ethyl acetate, } \\
\text { and Methanol }\end{array}$ & $\begin{array}{l}\text { Govindarajan et al., 2012; Rajeswary and } \\
\text { Govindarajan, 2014; Raman et al., } 2012\end{array}$ \\
\hline 2. & Antidiabetic & Seed & Methanol & Nagmoti et al., 2015 \\
\hline 3. & Hypolipidemic & Seed & Methanol & Nagmoti et al., 2015 \\
\hline \multirow[t]{2}{*}{4.} & Anti-oxidant & $\begin{array}{l}\text { Seed } \\
\text { Wood bark, leaf } \\
\text { Fruits }\end{array}$ & $\begin{array}{l}\text { Aqueous, Methanol } \\
\text { Methanol, acetone } \\
\text { Aqueous, hydro alcoholic }\end{array}$ & $\begin{array}{l}\text { Katekhaye and Kale, 2012; Nagmoti et al., 2012; } \\
\text { Sukantha et al., } 2011\end{array}$ \\
\hline & Anti-ulcer & Fruits & Hydro alcoholic & Megala and Geetha, 2011 \\
\hline 6. & Anti- venom & Bark & Hexane & Pithayanukul et al., 2005 \\
\hline 7 & Nephroprotective & Fruit & Aqueous & Pal et al., 2012 \\
\hline 8 & Anti-diarrheal & Leaves & Ethanol & Rashid et al., 2015 \\
\hline
\end{tabular}

and diabetes mellitus (Asmat et al., 2016; Mateen et al., 2016; Saegusa et al., 2006;). In our human body, various mechanisms like enzymatic and non-enzymatic antioxidants protect the inner cellular molecules and tissues against reactive oxygen species (ROS) induced damage (Aruoma, 1998).

The phytochemicals are widely known to be the precious sources for antioxidant activity. It stabilizes the radicals generated through various factor and help in promoting the antioxidant enzymes in our body. The leaves, seeds, fruits, and wood barks extract of $P$. dulce have potential activity against free radicals has proved. The whole plant has active free radical scavenging potential against synthetic radicals of $\mathrm{DPPH}, \mathrm{NO}$, superoxide, and hydroxyl ions (Katekhaye and Kale, 2012; Nagmoti et al., 2012; Sukantha et al., 2011). Further, the HPLC profiling confirms the 
abundant active phenolic and flavonoid contents in the fruits (Megala and Geetha, 2009).

\section{Anti-ulcer activity}

Peptic ulcer is one of the major and common global health issues. Because many of the anti-inflammatory drugs [called non-steroidal anti-inflammatory drugs (NSAIDS)], dietary factors, stress, or painkiller drugs were found to be affect the stomach and causes an ulcer (Lanas and Chan, 2017). Continuous alcoholic adductors are also affected by peptic ulcer. The development of ulcer is correlated with oxidative stress by hypersecretion of HCL and reactive oxygen species (ROS) generation (Osefo et al., 2009; Suzuki et al., 2012). The hypersecretion of HCL is caused by $\mathrm{H}^{+}, \mathrm{K}^{+}$-ATPase action. Omeprazole, Lansoprazole, Ranitidine, and Famotidine are the major $\mathrm{H}^{+}$and $\mathrm{K}^{+}$-ATPase inhibitors used to treat the ulcer and to control the acid secretion. But these anti-secretary drugs produce adverse side effects on the human body.

The aqueous crude extract of $P$. dulce was orally treated in acetylsalicylic acid (ASA)-induced rat model (Male albino Wistar rats). The phytocompounds reacted and inhibited the gastric mucosal $\mathrm{H}^{+}, \mathrm{K}^{+}$-ATPase (Megala and Geetha, 2009). The $\mathrm{H}^{+}, \mathrm{K}^{+}$ATPase level was analyzed and compared with the standard drug of Omeprazole. Gastric mucin is an important factor in protecting the gastric mucosa. Gastric mucin, myeloperoxidase activity, and prostaglandin E2 (PGE2) level were analyzed and reported in Megala and Geetha (2012). The important role of PGE2 is to maintain the gastric mucosa by increasing the gastric mucus secretion and decreasing the gastric acid secretion. In the $P$. dulce treated rats, the PGE2 level was found to be increased and that indicates the stimulation of cytoprotective factors that contribute to accelerate the ulcer healing effect. From the results, $P$. dulce have an ability to cure the gastrointestinal disorders (Peptic ulcer). So, the $P$. dulce extract can be used as an antiulcer agent and it also act as an anti-acid secreting agent and cytoprotective factor (Megala and Geetha, 2012).

\section{Nephroprotective}

Carbon tetrachloride $\left(\mathrm{CCl}_{4}\right)$ is an environmental toxin and is also used as medicine for hookworm disease and it affects and damages the kidney and liver (Rahmat et al., 2014). It causes fibrosis, cirrhosis, and hepatic carcinoma. Cytochrome P450 isozymes produce trichloromethyl free radical (TCCM free radicals) with higher toxicity of $\mathrm{CCl}_{4}$. TCCM Free radicals react with oxygen to form the reactive trichloromethyl peroxy radical (high level toxic), a reactive oxygen species (ROS). Free radical also induces the lipid peroxidation and it is a major factor for cell membrane damage in many pathological situations. $\mathrm{CCl}_{4}$ generates free radicals and cause renal disorders by generating free radicals in hepatic disorder (Al-Yahya et al., 2013). Pithecellobium dulce crude extract was orally administrated in the $\mathrm{CCl}_{4}$ induced rats (orally before $\mathrm{CCl}_{4}$ induced rat) and crude extract was also administrated to the rat before inducing $\mathrm{CCl}_{4}$ toxin (orally after $\mathrm{CCl}_{4}$ induced rat). The crude extract of $P$. dulce decreased the lipid peroxidation and protein carboxylation after inducing $\mathrm{CCl}_{4}$ in rats, as the $P$. dulce compounds have antioxidant activity. In the $\mathrm{CCl}_{4}$ administrated rats, the ROS level was found increased, while $P$. dulce fruit extract treated rats have decreased ROS level when compared with $\mathrm{CCl}_{4}$ administrated untreated rats. Anti-oxidants enzymes are mainly involved in cellular defense and to prevent and protect from oxidative stress or oxidative damage. Glutathione reductase (GR), Superoxide dismutase (SOD), Glutathione-S-transferase (GST), and catalase (CAT) are major antioxidant enzymes and CAT \& SOD are important enzymes to eliminate the ROX. In the $P$. dulce extract pretreated rats, higher amount of anti-oxidant enzyme level was observed as compared with $\mathrm{CCl}_{4}$ induced rats and the rats treated with $P$. dulce extract. The aqueous extract of $P$. dulce also prevents and protects the renal DNA damage and cell death, by means of stabilizing the oxidative radicals, which disturbs the mitochondrial membrane and causes loss of ATP production that directly leads to cell death. Pal et al. (2012) evaluated and proved the anti-necrotic properties and nephroprotective properties of P. dulce.

\section{Anti-venom effect}

The tannin was extracted from $P$. dulce barks using aqueous extraction. The venom lethality was inhibited and the necrotizing activity of the venom was minimized by this crude extract. The extract also inhibited $90 \%$ of acetylcholine esterase activity as it contains higher tannin concentration or combined hydrolyzable tannin concentration. $\alpha$-cobra toxin protein was docked with four different tannin compounds using Autodock 3 and tannic acid, Digallic acid has $-14.7 \mathrm{kcal} / \mathrm{mol},-10.38 \mathrm{kcal} /$ mol binding energies were studied. The plant extract selectively blocks nicotinic acetylcholine receptor and non-selectively precipitate the venom protein (Pithayanukul et al., 2005).

\section{Anti-diarrheal effect}

The ethanolic extract of $P$. dulce showed an antidiarrheal effect in the castor oil-induced mice. Loperamide is the standard anti-diarrheal drug used to compare the results. The phytochemicals of $P$. dulce has the ability to increase the latent period, delay, and decrease the frequency of defecation (Rashid et al., 2014).

\section{Anti-bacterial effect}

The ethanolic extract of $P$. dulce pod pulp has potent to inhibit the Gram-positive bacteria (Bacillus subtilis) and Gramnegative bacteria (Klebsiella pneumonia). The secondary metabolites (flavonoid, saponin, etc.) are responsible for the inhibition of bacterial growth (Pradeepa et al., 2014). The aqueous, methanolic and ethyl acetate extract of $P$. dulce fruit peel inhibit the eight different microorganisms (Staphylococcus epidermis, Escherichia coli, Klebsiella pneumonia, Staphylococcus aureus, Enterococcus faecalis, Pseudomonas aeruginosa, Pseudomonas putida, and Proteus vulgaris) isolated from wound infection. The higher zone inhibition was found in the crude methanolic extract. From the result, $P$. dulce fruit peel metabolites could be used as an antimicrobial agent and wound healing agent was proved. The ethanolic extract of P. dulce leaf has also been investigated and their effective antibacterial property was reported by Sukantha et al., 2014.

\section{Anti-fungal effect}

The plant pathogens like fungus cause contamination in strawberry fruits during storage. Many of the preventive agents are used to prevent fungal contamination on fruits but they are usually 
holding some toxic effects. Pithecellobium dulce is a natural resource that could be used against fungal contamination. The aqueous and hydroalcoholic extracts of $P$. dulce have potentiality against Rhizopus stolonifer, Botrytis cinerea, and Penicillium digitatum contamination. In the aqueous extract, the secondary metabolite of kaempferol and some other mixture of compounds are mainly involved against the fungal contamination. While comparing the aqueous and hydro alcoholic extracts, the aqueous extract has better activity against fungal contamination (BautistaBanos et al., 2003; Shanmugakumar et al., 2006).

\section{CONCLUSION}

The present review concludes that this $P$. dulce has several beneficiary health effects and pharmaceutical activities such as anti-ulcer, anti-fungal, anti-diabetic, and anti-venom activities. From this review, presents a comprehensive view of the plant $P$. dulce physiological, pharmaceutical properties, and traditional applications of $P$. dulce. The origin, distribution, nutritional, metabolites, and pharmaceutical properties information given above will be beneficiary to the society over various health issues. Further, this study encourages consuming traditionally practiced herbs and fruits to face modern life-threatening illness.

\section{CONFLICT OF INTEREST}

All authors declare that there is no conflict of interests regarding publication of this paper.

\section{FINANCIAL SUPPORT AND SPONSORSHIP}

None.

\section{REFERENCES}

Al-Yahya MA, Mothana R, Al-Said M. Attenuation of CCl4induced oxidative stress and hepatonephrotoxicity by Saudi Sidr honey in rats. J Evid Based Complementary Altern Med, 2013; 1-10.

Aruoma OI. Free radicals, oxidative stress, and antioxidants in human health and disease. J Am Oil Chem Soc, 1998; 75:199-212.

Asmat U, Abad K, Ismail K. Diabetes mellitus and oxidative stress-a concise review. Saudi Pharm J, 2016; 24:547-53.

Bagchi S, Kumar KJ. Studies on water soluble polysaccharides from Pithecellobium dulce (Roxb.) Benth. Seeds. Carbohydr Polym, 2016; 138:215-21.

Bautista-Banos S, Garcia-Dominguez E, Barrera-Necha LL, Reyes-Chilpa R, Wilson CL. Seasonal evaluation of the postharvest fungicidal activity of powders and extracts of huamuchil (Pithecellobium dulce): action against Botrytris cinerea, Penicillium digitatum and Rhizopus stolonifer of strawberry fruit. Postharvest Biol Technol, 2003; 29:81-92.

Bhargvakrishna P, Gupta MB, Mitra CR, Chittranjan R. Antiinflammatory activity of saponins and other natural products. Indian J Med Res, 1970; 58:724-30.

Chaudhury A, Duvoor C, Reddy Dendi VS, Kraleti S, Chada A, Ravilla R, Marco A, Shekhawat NS, Montales MT, Kuriakose K, Sasapu A, Beebe A, Patil N, Musham CK, Lohani GP, Mirza W. Clinical review of antidiabetic drugs: implications for type 2 diabetes mellitus management. Front Endocrinol, 2017; 8:6.

CSIR. The useful plants of India, publ. info. Directorae. New Delhi, India: C.S.I.R. (Council of Scientific and Industrial Research); 1988.

Edzard Ernst MD. Harmless herbs? A review of the recent literature. Am J Med, 1998; 170-8.

$\mathrm{Fu} \mathrm{Z}$, Gilbert ER, Liu D. Regulation of insulin synthesis and secretion and pancreatic Beta-cell dysfunction in diabetes. Curr Diabetes Rev, 2013; 9:25-53.
Gao Y, Zhang M, Wu T, Xu M, Cai H, Zhang Z. Effects of D-pinitol on insulin resistance through the PI3K/Akt signaling pathway in type 2 diabetes mellitus rats. J Agric Food Chem, 2015; 63:6019-26.

Govindarajan M, Rajeswary M. Repellent properties of Pithecellobium dulce (Roxb.) Benth. (Family: Fabaceae) against fi lariasis vector, Culex quinquefasciatus Say (Diptera:Culicidae). J Med Herbs Ethnomed, 2015; 1:103-7.

Govindarajan M, Sivakumar R, Rajeswary M, Yogalakshmi K. Adulticidal activity of Pithecellobiumdulce (Roxb.) Benth. Against Culexquinquefasciatus(Say). Asian Pacific J Trop Dis, 2012; 1:124-8.

Kahindi RK, Abdulrazak SA, Muinga RW. Effect of supplementing Napier grass (Pennisetum purpureum) with Madras thorn (Pithecellobium dulce) on intake, digestibility and live weight gains of growing goats. Small Ruminant Res, 2007; 69:83-7.

Katekhaye SD, Kale MS. Antioxidant and free radical scavenging activity of Pithecellobium dulce (Roxb.) Benth wood bark and leaves. Free Radic Biol Med, 2012; 2:47-57.

Kim MJ, Yoo KH, Kim JH. Effect of pinitol on glucose metabolism and adipocytokines in uncontrolled type 2 diabetes. Diabetes Res Clin Pract, 2007; 77:247-51.

Hooper L, Cassidy A. A review of the health care potential of bioactive compounds. J Sci Food Agric, 2006; 86:1805-13.

Lanas A, Chan FKL. Peptic ulcer disease. Lancet, 2017; 613-24.

Mateen S, Moin S, Khan AQ, Zafar A, Fatima N. Increased reactive oxygen species formation and oxidative stress in rheumatoid arthritis increased reactive oxygen species formation and oxidative stress in rheumatoid arthritis. PLoS One, 2016; 11:e0152925.

Megala J, Geetha A. Free radical- scavenging and $\mathrm{H}^{+}, \mathrm{K}^{+}$ ATPase inhibition activities of Pithecellobium dulce. Food Chem, 2009; 121:1120-8.

Megala J, Geetha A. Antiulcerogenic activity of hydroalcoholic fruit extract of Pithecellobium dulce in different experimental ulcer models in rats. J of Ethnopharmacol, 2012; 142:415-21.

Nagmoti DM, Kothavade PS, Bulani VD, Gawali NB, Juvekar AR. Antidiabetic and antihyperlipidemic activity of Pithecellobium dulce (Roxb.) Benth seeds extract in streptozotocin-induced diabetic rats. Eur J Integrative Med, 2015; 7:263-73.

Nelson RH. Hyperlipidemia as a risk factor for cardiovascular disease. Prim Care, 2013; 40:195-211.

Nigam SK, Gupta RK, Mitra CR. Pithecellobium dulce. I. Isolation and characterization of the constituents of the legume. J Pharm Sci, 1962; 52:459-62.

Nigam SK, Misra G, Uddin R, Yoshikawa K, Kawamoto M, Arihara S. Pithedulosides A-G, Oleanane glycosides from Pithecellobium dulce. Phytochem, 1996; 44:1329-34

Nigam SK, Mitra CR. Pithecellobium dulce. IV. Constituents of flowers, heartwood, and root bark. Planta Med, 1968; 16:335-7.

Nigam SK, Mitra CR. Pithecellobium dulce. V. Chemistry of the seed saponin and constituents of the leaves. Planta Med, 1970; 18:44-50.

Olivares JF, Avilés NF, Albarrán PB, Castelán OA, Rojas HS Nutritional quality of Pithecellobium dulce and Acacia cochliacantha fruits, and its evaluation in goats. Livest Sci, 2013; 154:74-81.

Orwa C, Mutua A, Kindt R, Jamnadass R, Simons A Agroforestree database: a tree species reference and selection guide version 4.0. World Agroforestry Centre ICRAF, Nairobi, KE, 2009.

Osefo N, Ito T, Jensen RT. Gastric acid hypersecretory states: recent insights and advances. Curr Gastroenterol Rep, 2009; 11:433-41.

Pal PB, Pal S, Manna P, Sil PC. Traditional extract of Pithecellobium dulce fruits protects mice against $\mathrm{CCl} 4$ induced renal oxidative impairment and necrotic cell death. Pathophysiology, 2012; 19:101-14.

Pirkle JL, Freedman BI. Hypertension and chronic kidney disease: controversies in pathogenesis and treatment. Minerva Urol Nefrol, 2013; 65:37-50.

Pithayanukul P, Ruenraroengsak P, Bavovada R, Pakmanee N, Suttisri R, Saen-oon S. Inhibition of Naja kaouthia venom activities by plant polyphenols. J Ethnopharmacol, 2005; 97:527-33. 
Pradeepa S, Subramanian S, Kaviyarasan V. Evaluation of antimicrobial activity of Pithecellobium dulce pod pulp extract. Asian J Pharm Clin Res, 2014; 7:32-7.

Preethi S, Mary Saral A. Screening of natural polysaccharides extracted from the fruits of Pithecellobium dulce as a pharmaceutical adjuvant. In J Bio Mac, 2016; 92:347-56.

Rahmat AA, Dar FA, Choudhary IM. Protection of $\mathrm{CCl}_{4}$-induced liver and kidney damage by phenolic compounds in leaf extracts of Cnestis ferruginea (de Candolle). Pharmacogn Res, 2014; 6:19-28.

Rajeswary M, Govindarajan M. Adulticidal properties of Pithecellobiumdulce (Roxb.) Benth. (Family: Fabaceae) against dengue vector, Aedes aegypti (Linn.) (Diatera: Culicidae). Asian Pacific J Trop Dis, 2014; 1:449-52.

Raman N, Sudharsan S, Veerakumar V, Pravin N, Vithiya K. Pithecellobiumdulce mediated extra-cellular green synthesis of larvicidal silver nanoparticles. Spec Acta Part A Mol Biomol Spec, 2012; 96: 1031-7.

Rao GN, Nagender A, Satyanarayana A, Rao DG. Preparation, chemical composition and storage studies of quamachil (Pithecellobium dulce L.) aril powder. J Food Sci Technol, 2010; 48(1):90-5.

Rashid MH, Biswas SU, Abdullah-AL-Mamun MO, huque A, Bhuiyan JR. Phytochemical screening and analgesic, anti-bacterial and cytotoxic activity evaluation of ethanol extract of Pithcellobium dulce (Roxb.) benth leaf. Asian J Pharm Clin Res, 2015; 8:451-6.

Saegusa J, Kawano S, Kumagai S. Oxidative stress and autoimmune diseases. Oxid Stress Dis Cancer, 2006; 461-75.

Sahu NP, Mahato SB. Anti-inflammatory triterpene saponins of Pithecellobium dulce: characterization of echinocystic acid bisdesmoside. Phytochem, 1994; 37:1425-7.

Saklani A, Kutty SK. Plant-derived compounds in clinical trials. Drug Discov Today, 2008; 13:161-71.

Satheesh Kumar N, Nisha N. Phytomedicines as potential inhibitors of $\beta$ amyloid aggregation: significance to Alzheimer's disease. Chin J Nat Med, 2014; 12:801-18.

Saxena VK, Singhal M. Novel prenylated flavonoid from stem of Pithecellobium dulce. Fitoterapia, 1999; 70:98-100.

Shanmugakumar SD, Amerjothy S, Balakrishna K. Pharmacognostical, antibacterial and antifungal potentials of the leaf extracts of Pithecellobium dulce Benth. Phcog Mag, 2006; 2:163-7.

Shyur LF, Yang NS. Metabolomics for phytomedicine research and drug development. Curr Opin Chem Biol, 2008; 12:66-71.
Sukantha TA, Subashini KS, Ravindran NT, Balashanmugam P. Evaluation of in vitro antioxidant and antibacterial activity of Pithecellobium dulce Benth fruit peel. Int J Curr Res, 2011; 1:378-82.

Sukantha TA, Subashini KS, Ravindran NT. Antibacterial activity of selected medicinal plant in traditional treatment of wound infection in Southeast India. Int J Pharm Sci, 2014; 6:511-3.

Sukantha TA, Subashini KS. Isolation and characterization of secondary metabolites from Pithecellobium dulce benth fruit peel. Int J Pharm Pharm Sci, 2015; 7:199-203.

Suzuki H, Nishizawa T, Tsugawa H, Mogami S, Hibi T. Roles of oxidative stress in stomach disorders. J Clin Biochem Nutr, 2012; 50:35-9.

Ung L, Pattamatta U, Carnt N, Wilkinson-Berka JL, Liew G, White AJ. Oxidative stress and reactive oxygen species: a review of their role in ocular disease. Clin Sci 2017; 131:2865-83.

Vergeer M, Holleboom AG, Kastelein JJ, Kuivenhoven JA. The HDL hypothesis: does high-density lipoprotein protect from atherosclerosis? J Lipid Res, 2010; 51:2058-73.

Yoshikawa K, Suzaki Y, Tanaka M, Arihara S, Nigam SK. Three acylated saponins and a related compound from Pithecellobium dulce. J Nat Prod, 1997; 60:1269-74.

Zhou X, Zhang W, Liu X, Zhang W, Li Y. Interrelationship between diabetes and periodontitis: role of hyperlipidemia. Arch Oral Biol, 2015; 60:667-74.

How to cite this article:

Selvakumar M, Dinesh Kumar L, Velusamy A, Ronaldo Anuf A. Nutritional and therapeutic benefits of medicinal plant Pithecellobium dulce (Fabaceae): A review. J Appl Pharm Sci, 2019; 9(07):130-139. 